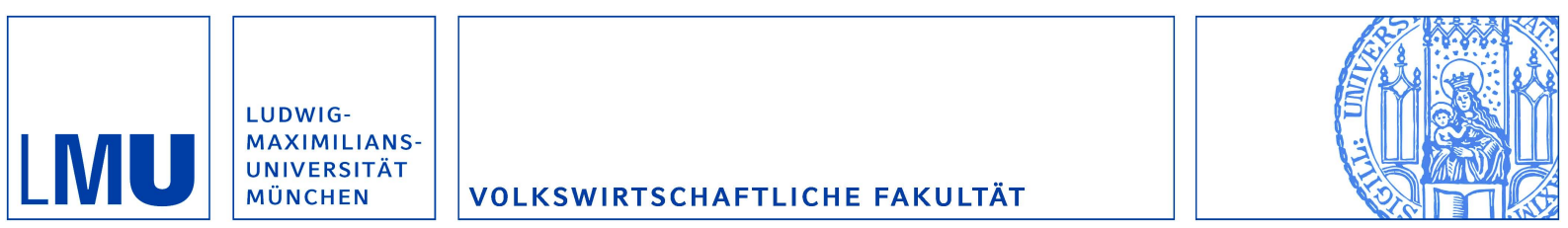

Bucovetsky, Sam und Haufler, Andreas:

Preferential tax regimes with asymmetric countries

Munich Discussion Paper No. 2006-30

Department of Economics

University of Munich

Volkswirtschaftliche Fakultät

Ludwig-Maximilians-Universität München

Online at https://doi.org/10.5282/ubm/epub. 1209 


\title{
Preferential tax regimes with asymmetric countries *
}

\author{
Sam Bucovetsky \\ Andreas Haufler \\ York University, Toronto \\ University of Munich
}

October 3, 2006

\begin{abstract}
Current policy initiatives taken by the EU and the OECD aim at abolishing preferential corporate tax regimes. This note extends Keen's (2001) analysis of symmetric capital tax competition under preferential (or discriminatory) and non-discriminatory tax regimes to allow for countries of different size. Even though size asymmetries imply a redistribution of tax revenue from the larger to the smaller country, a non-discrimination policy is found to have similar effects as in the symmetric model: it lowers the average rate of capital taxation and thus makes tax competition more aggressive in both the large and the small country.

Keywords: corporate taxation, preferential tax regimes
\end{abstract}

JEL-Classification: H 73, H 25

*Address for correspondence: Andreas Haufler, Seminar for Economic Policy, University of Munich, Akademiestr. 1 / II, D-80799 Munich, Germany. Tel.: +49 892180 3858, e-mail: Andreas.Haufler@lrz.uni-muenchen.de. 


\section{Summary}

One of the main current policy issues in corporate taxation is the abolition of preferential tax regimes. Many countries grant tax preferences to foreign-based multinational firms in order to attract internationally mobile tax bases, while simultaneously maintaining a higher effective rate of taxation for less mobile domestic firms. This practice of 'ring-fencing' the domestic tax base has come under heavy attack from both the OECD and the European Commission. From a theoretical point of view it is unclear, however, whether the abolition of preferential tax regimes is indeed desirable from a global economic efficiency perspective. In particular, it has been shown by Keen (2001) that tax competition might become more aggressive when countries are forced to tax all firms at the same rate, but are free to adjust this tax rate in a non-cooperative way. This analysis - as well as most related work - assumes, however, that the two competing countries are identical in all respects. Given the evidence that preferential tax regimes are primarily used by small countries this is clearly an important restriction. In this short paper we extend Keen's (2001) analysis of discriminatory vs. nondiscriminatory tax competition to allow for tax competition between countries of different size. We ask whether large countries - the principal supporters of the policy initiatives referred to above - may gain from the abolition of tax preferences, by restricting the ability of small countries to compete with them on unequal terms. Our analysis shows that the smaller country unambiguously has lower tax rates and higher per-capita tax revenue, under either restricted or unrestricted tax competition. However, imposing a non-discrimination constraint hurts not only the small but also the large country. Hence Keen's (2001) finding extends to the introduction of size asymmetries between countries. The intuition for this result is that the ratio of tax rates, and thus the degree of tax discrimination, is the same in both countries. Revenue changes are thus solely determined by the adjustment in the average rate of capital taxation. The average tax rate will fall in both countries, and tax competition will be intensified, because it becomes more attractive to compete for the more mobile base when the tax rate on this base is increased by a non-discrimination constraint.

Our result is relevant for the non-discrimination policies enacted at the OECD and EU levels, which are primarily targeted at the tax practices of small countries and territories. It reinforces the warning that such partial coordination policies can be welfare-reducing when countries are free to set (uniform) tax rates independently. 


\section{Introduction}

One of the main current policy issues in corporate taxation is the abolition of preferential tax regimes. Many countries grant tax preferences to foreign-based multinational firms in order to attract internationally mobile tax bases, while simultaneously maintaining a higher effective rate of taxation for less mobile domestic firms. ${ }^{1}$ This practice of 'ring-fencing' the domestic tax base has come under heavy attack from both the OECD and the European Commission. The OECD $(1998,2000)$ has issued a blacklist of predominantly small tax havens, which have been induced to discontinue granting specific tax preferences to foreign-based multinational firms. At the same time, the European Union has identified a total of 66 discriminatory measures, mostly taken by small EU countries and associated territories, which are to be phased out by 2008 (Primarolo Report, 1999).

From a theoretical point of view it is unclear, however, whether these measures are indeed desirable from a global economic efficiency perspective. In particular, it is feared that overall tax competition might be intensified when countries are forced to abolish tax preferences, which are primarily targeted at multinational firms. This is most clearly expressed in the analysis of Keen (2001), who shows that when two symmetric countries compete for two different tax bases, both of which are internationally mobile (albeit to a different degree), the restriction to employ a single tax rate on both tax bases will unambiguously reduce tax revenues in each country. Later work has qualified Keen's result and has shown that a ban on tax preferences need not be revenue-reducing if either the size of the two tax bases is not given for the two countries taken together (Janeba and Smart, 2003), or if investors in each country exhibit a home bias (Haupt and Peters, 2005). ${ }^{2}$ Nevertheless, Keen's result is still a forceful one.

All the above-mentioned contributions assume, however, that the two competing coun-

\footnotetext{
${ }^{1}$ The reduced tax burden of multinational firms is documented in a recent study by Hines (2005). Using firm-specific data from the U.S. Bureau of Economic Analysis, Hines shows (Table 1) that the effective profit tax burden of U.S.-based multinationals has, on average, fallen more strongly since the 1980s than the nominal corporate income tax rates of the host countries. This finding indicates either that U.S. multinationals have benefitted from discriminatory tax breaks or that they have been able to shift profits to tax havens (or a combination of both).

${ }^{2}$ Recently, Bucovetsky and Haufler (2006) have considered a model where firms can invest in a multinational structure that allows them to benefit from tax preferences. In this setting the welfare effects of restricting tax preferences depend critically on the elasticity with which firms change their organizational form in response to tax incentives.
} 
tries are identical in all respects. ${ }^{3}$ Given the evidence that preferential tax regimes are primarily used by small countries this is clearly an important restriction. A well-known result from the literature on asymmetric tax competition for a single tax base is that small countries will undercut their larger neighbors, and may even be better off under tax competition as compared to a situation where countries can fully coordinate their tax rates (Bucovetsky, 1991; Wilson, 1991; Kanbur and Keen, 1993). ${ }^{4}$ It is thus a natural question to ask whether large countries - the principal supporters of the policy initiatives referred to above - may gain from the abolition of tax preferences, by restricting the ability of small countries to compete with them on unequal terms.

In this short paper we combine Keen's (2001) analysis of discriminatory vs. nondiscriminatory tax competition with the analysis of tax competition between countries of different size. We show that the smaller country unambiguously has lower tax rates, but higher per-capita tax revenue, under either restricted or unrestricted tax competition. However, imposing a non-discrimination constraint hurts not only the small country, but also the large one. Hence Keen's (2001) result turns out to be robust with respect to the introduction of size asymmetries between countries.

\section{The model with differentiated taxation}

We consider two countries $i \in\{A, B\}$ which compete over two capital tax bases. The share of country $i$ in the world population is $s^{i}$ and, by convention, we let country A be the smaller of the two countries (so that $s^{A} \leq 0.5$ and $s^{B} \geq 0.5$ ). There are two distinct capital tax bases $n \in\{1,2\}$, which differ in their degree of international mobility. One interpretation is that the first base captures the profits of large, multinational firms, which can easily shift profits across countries, whereas the second base represents

\footnotetext{
${ }^{3}$ An exception is the early analysis by Janeba and Peters (1999), which assumes that countries differ in the size of their (completely immobile) domestic tax base while competing for a second tax base that is perfectly mobile internationally. In this model there is no symmetric equilibrium in pure strategies. There exists, however, a symmetric equilibrium in mixed strategies that is analyzed by Wilson (2005). Wilson shows that whenever the domestic tax base has some degree of international mobility, the abolition of tax preferences reduces expected revenue, in line with the result in Keen (2001).

${ }^{4}$ See Wilson (1999) for a survey. More recently, Hong and Smart (2005) and Slemrod and Wilson (2006) have evaluated the effects that the presence of small tax havens has on global welfare, with opposite conclusions being reached in the two analyses.
} 
the profits of smaller firms, which can invest abroad but have fewer possibilities for international profit shifting. The aggregate supply of each capital tax base is fixed. Each type of capital is combined with sector-specific labor that is immobile across countries. The smaller country $A$ has the same share of workers in each sector; hence $s^{i}$ bears no subscript. Shares sum to unity, $s^{A}+s^{B}=1$. We employ the per-capita notation that is customary in the analysis of countries of different size and let $k_{n}^{i}$ denotes the per-capita employment of the capital base $n$ in country $i$. Hence market clearing for both types of capital implies

$$
s^{A} k_{n}^{A}+s^{B} k_{n}^{B}=\bar{k}_{n} \quad \forall n \in\{1,2\} .
$$

where $\bar{k}_{n}$ is the fixed supply of tax base $n$. To arrive at reduced-form expressions in our analysis we assume that the production functions in both sectors $n \in\{1,2\}$ are quadratic. The production functions differ across sectors but, for each sector, are the same across countries. Per-capita production in country $i$ and in sector $n$ is $f_{n}^{i}=$ $a_{n} k_{n}^{i}-0.5 b_{n}\left(k_{n}^{i}\right)^{2}$, leading to linear marginal productivity conditions for each type of capital

$$
\frac{\partial f_{n}^{i}}{\partial k_{n}^{i}}=a_{n}-b_{n} k_{n}^{i} \quad \forall i \in\{A, B\}, n \in\{1,2\} .
$$

The slope parameter $b_{n}$ may differ between tax bases.

Following a standard procedure in the literature, we assume that taxes are levied as source-based unit taxes on capital. Without loss of generality, we impose as well the normalization on units of quantity that

$$
a_{1}-b \bar{k}_{1}=a_{2}-b \bar{k}_{2}
$$

Together with the assumption of quadratic technologies, this normalization ensures that equal unit taxes on each type of capital are equivalent to equal ad valorem tax rates. From (2), net-of-tax arbitrage by internationally mobile investors implies

$$
t_{n}^{B}-t_{n}^{A}=b_{n}\left(k_{n}^{A}-k_{n}^{B}\right) \quad \forall n \in\{1,2\} .
$$

Using (1) in (4) we can derive per-capita tax bases in each country as a function of the two tax rates

$$
k_{n}^{i}=\bar{k}_{n}+\frac{\left(1-s^{i}\right)}{b_{n}}\left(t^{j}-t^{i}\right) \quad \forall i, j \in\{A, B\}, i \neq j, n \in\{1,2\} .
$$

Differentiating $k_{n}^{i}$ in (5) with respect to $t^{i}$ shows that the response of either capital tax base to a tax change is larger, in per-capita terms, for the smaller country $A$. From (5), 
the net return to capital of type $n, r_{n}=f^{\prime}\left(k_{n}^{A}\right)-t_{n}^{A}=f^{\prime}\left(k_{n}^{B}\right)-t_{n}^{B}$ must be

$$
r_{n}=a_{n}-b_{n} \bar{k}_{n}-s^{A} t_{n}^{A}-s^{B} t_{n}^{B} .
$$

As in Keen (2001), governments are assumed to maximize tax revenues. In the benchmark case, each government is allowed to levy differentiated tax rates (subscript $D$ ) on the different capital tax bases. Hence each government maximizes

$$
T_{D}^{i}=t_{1}^{i} k_{1}^{i}+t_{2}^{i} k_{2}^{i} \quad \forall i \in\{A, B\} .
$$

Substituting capital tax bases from (5) and differentiating with respect to $t_{n}^{i}$ yields Nash equilibrium tax rates in reduced form

$$
t_{n}^{A *}=\frac{b_{n} \bar{k}_{n}\left(1+s^{A}\right)}{3 s^{A} s^{B}}, \quad t_{n}^{B *}=\frac{b_{n} \bar{k}_{n}\left(1+s^{B}\right)}{3 s^{A} s^{B}} \quad \forall n .
$$

In each country, the tax rate on tax base $n$, expressed as a fraction of its gross return, will be proportional to the elasticity of that return with respect to the supply of capital. The "more mobile" tax base is the one for which $b_{n} \bar{k}_{n}$ is lower, implying a greater sensitivity of capital supply to its net return. Moreover, the equilibrium tax rates show that the smaller country (country A) levies the lower tax rate on each tax base $n$. Finally, and importantly, it follows from (7) that the large and the small country choose the same ratio of tax rates, $t_{1}^{i} / t_{2}^{i}$, and hence grant the same relative tax advantage to the more mobile type of capital.

In equilibrium

$$
k_{n}^{i}=\left[1+\frac{\left(s^{j}-s^{i}\right)\left(1-s^{i}\right)}{3 s^{A} s^{B}}\right] \bar{k}_{n} \quad \forall i, j \in\{A, B\}, i \neq j, n \in\{1,2\},
$$

implying that country $i$ gets the same share of each tax base, with the smaller country getting the larger share.

Substituting the optimal non-cooperative tax rates (7) along with the tax base expressions (8) in the objective function (6) gives optimized per-capita tax revenue in each country when tax rates can be differentiated:

$$
T_{D}^{A *}=\frac{\left(1+s^{A}\right)^{2}}{9\left(s^{A}\right)^{2} s^{B}}\left(b_{1} \bar{k}_{1}^{2}+b_{2} \bar{k}_{2}^{2}\right), \quad T_{D}^{B *}=\frac{\left(1+s^{B}\right)^{2}}{9 s^{A}\left(s^{B}\right)^{2}}\left(b_{1} \bar{k}_{1}^{2}+b_{2} \bar{k}_{2}^{2}\right) .
$$

Comparing the two expressions in (9) gives

$$
T_{D}^{A *}-T_{D}^{B *}=\frac{b_{1} \bar{k}_{1}^{2}+b_{2} \bar{k}_{2}^{2}}{9\left(s^{A}\right)^{2}\left(s^{B}\right)^{2}}\left[\left(s_{B}\right)^{3}-\left(s^{A}\right)^{3}\right]>0 .
$$

Hence, per-capita tax revenue is higher in the smaller country. This corresponds to the well-known result that the small country achieves a higher welfare level in the Nash equilibrium than its larger neighbor (Bucovetsky, 1991; Wilson, 1991). 


\section{Introducing a non-discrimination constraint}

We now consider the case where each country must levy a uniform tax rate (subscript $U)$ on the two capital tax bases. This captures the constraint that tax preferences for the more mobile type of capital are abolished, while leaving each country full autonomy over its own overall level of capital taxation. The objective function changes to

$$
T_{U}^{i}=t^{i}\left(k_{1}^{i}+k_{2}^{i}\right) \quad \forall i
$$

Tax bases are again given by (5). Substituting into (11) and differentiating with respect to $t^{i}$ yields uniform Nash equilibrium tax rates

$$
t_{U}^{A *}=\frac{b_{1} b_{2}\left(\bar{k}_{1}+\bar{k}_{2}\right)\left(1+s^{A}\right)}{3 s^{A} s^{B}\left(b_{1}+b_{2}\right)}, \quad t_{U}^{B *}=\frac{b_{1} b_{2}\left(\bar{k}_{1}+\bar{k}_{2}\right)\left(1+s^{B}\right)}{3 s^{A} s^{B}\left(b_{1}+b_{2}\right)} .
$$

Again, the smaller country A chooses the lower tax rate in equilibrium.

Substituting each country's non-cooperative tax rate (12) and (5) into (11) gives optimized per-capita tax revenue in each country in the non-discriminatory tax regime:

$$
T_{U}^{A *}=\frac{b_{1} b_{2}\left(\bar{k}_{1}+\bar{k}_{2}\right)^{2}\left(1+s^{A}\right)^{2}}{9\left(s^{A}\right)^{2} s^{B}\left(b_{1}+b_{2}\right)}, \quad T_{U}^{B *}=\frac{b_{1} b_{2}\left(\bar{k}_{1}+\bar{k}_{2}\right)^{2}\left(1+s^{B}\right)^{2}}{9 s^{A}\left(s^{B}\right)^{2}\left(b_{1}+b_{2}\right)} .
$$

Comparing the two expressions in (13) shows that per-capita tax revenue is again higher in the smaller country:

$$
T_{U}^{A *}-T_{U}^{B *}=\frac{b_{1} b_{2}\left(\bar{k}_{1}+\bar{k}_{2}\right)^{2}}{9\left(s^{A}\right)^{2}\left(s^{B}\right)^{2}\left(b_{1}+b_{2}\right)}\left(s^{B}-s^{A}\right)\left(1-s^{A} s^{B}\right)>0 .
$$

The core question is whether tax revenues in each country are raised or lowered when the non-discrimination rule is introduced. In contrast to the symmetric case, we must also consider the possibility that one country gains, but the other country loses from the constraint to set a uniform tax rate on both capital tax bases. Forming the difference between optimized tax revenue in the two different scenarios gives:

$$
T_{D}^{A *}-T_{U}^{A *}=\frac{\left(1+s^{A}\right)^{2}}{9\left(s^{A}\right)^{2} s^{B}} \Omega, \quad T_{D}^{B *}-T_{U}^{B *}=\frac{\left(1+s^{B}\right)^{2}}{9 s^{A}\left(s^{B}\right)^{2}} \Omega,
$$

where the common factor $\Omega$ is given by

$$
\Omega=\frac{\left(b_{1} \bar{k}_{1}-b_{2} \bar{k}_{2}\right)^{2}}{\left(b_{1}+b_{2}\right)} \geq 0
$$

This expression must be non-negative, and will equal zero only if $b_{1} \bar{k}_{1}=b_{2} \bar{k}_{2}$. As in Keen (2001), the uniformity constraint will not affect tax revenues if both tax bases 
are equally mobile, so that no preferences arise in the unconstrained equilibrium. Otherwise, both countries lose from the non-discrimination constraint and Keen's finding generalizes to the case where countries differ in size. To understand the intuition for this result, it is useful to start with the benchmark case of symmetric countries. In this case both countries raise the tax rate on the more mobile base due to the nondiscrimination constraint, but also reduce the tax rate on the less mobile base, relative to the case of differentiated tax setting. As the tax rate on the more mobile base is increased, it becomes more attractive to compete for this base. ${ }^{5}$ Hence tax competition will be intensified, on average, and the uniform tax rate will be below the (arithmetic) average of the differentiated tax rates. ${ }^{6}$

This reasoning continues to hold when countries differ in size. Recall from (7) that, if tax discrimination is allowed, the ratio of tax rates $t_{1}^{i} / t_{2}^{i}$ and thus the degree of tax discrimination is the same in both countries. Therefore, the restriction to impose a uniform tax rate will affect both countries symmetrically. Revenue changes are thus solely determined by the adjustment in the average rate of capital taxation and equilibrium tax revenue will fall in both countries as a result of the non-discrimination constraint.

\section{Conclusion}

In this note we have extended Keen's (2001) analysis of symmetric tax competition under discriminatory and non-discriminatory tax regimes to allow for size differences between countries. In both regimes the well-known result reappears that the smaller country levies lower tax rates than its larger neighbor and a redistribution of tax revenues occurs, in the Nash equilibrium, from the larger to the smaller country. Nevertheless, a non-discrimination policy will have similar effects as in the symmetric model: it reduces the average level of capital taxation and thus tax revenues in both countries. This result is relevant for the non-discrimination policies enacted at the OECD and EU levels, which are primarily targeted at the tax practices of small countries and territories. It reinforces the warning that such partial coordination policies can be welfare-reducing when countries are free to set (uniform) tax rates independently. It

\footnotetext{
${ }^{5}$ See Janeba and Smart (2003, p. 266), who term this the 'strategic effect' of the restriction.

${ }^{6}$ This follows directly from (15) and the fact that the aggregate tax base $k_{1}^{i}+k_{2}^{i}$ is the same for each country in the discriminatory and non-discriminatory regimes. The proof is available from the authors upon request.
} 
should be emphasized, however, that our findings do not invalidate the arguments raised in the literature in favor of a ban on tax discrimination (see Janeba and Smart, 2003; Haupt and Peters, 2005; Bucovetsky and Haufler, 2006). Instead the main purpose of our analysis has been to show that the symmetry assumption used in much of this literature is perhaps less crucial than first intuition may suggest. 


\section{References}

Bucovetsky, S. (1991), Asymmetric tax competition. Journal of Urban Economics 30, 167-181.

Bucovetsky, S. and A. Haufler (2006), Tax competition when firms choose their organizational form: Should tax loopholes for multinationals be closed? Revised, York University and University of Munich.

Haupt, A. and W. Peters (2005), Restricting preferential tax regimes to avoid harmful tax competition. Regional Science and Urban Economics 35, 493-507.

Hines, J.R. (2005), Corporate taxation and international competition. Ross School of Business Paper 1026. University of Michigan.

Hong, Q. and M. Smart (2005), In praise of tax havens: International tax planning and foreign direct investment. Mimeo, University of Toronto.

Kanbur, R. and M. Keen (1993), Jeux sans frontières: Tax competition and tax coordination when countries differ in size. American Economic Review 83, 877-892.

Janeba, E. and W. Peters (1999), Tax evasion, tax competition and the gains from nondiscrimination: The case of interest taxation in Europe. The Economic Journal 109, 93-101.

Janeba, E. and M. Smart (2003), Is targeted tax competition less harmful than its remedies? International Tax and Public Finance 10, 259-280.

Keen, M. (2001), Preferential regimes can make tax competition less harmful. National Tax Journal 54, 757-762.

OECD (1998), Harmful tax competition: An emerging global issue. Paris.

OECD (2000), Towards global tax co-operation. Progress in identifying and eliminating harmful tax practices. Paris

Primarolo Report (1999), Report from the Code of Conduct Group to the ECOFIN Council. Brussels, 29 November 1999.

Slemrod, J.B. and J.D. Wilson (2006), Tax competition and parasitic tax havens. NBER Working Paper No. W12225. 
Wilson, J.D. (1991), Tax competition with interregional differences in factor endowments. Regional Science and Urban Economics 21, 423-451.

Wilson, J.D. (1999), Theories of tax competition. National Tax Journal 52, 269-304.

Wilson, J.D. (2005), Tax competition with and without preferential treatment of a highly-mobile base. In: J. Alm, J. Martinez-Vazquez and M. Rider (eds.), The challenges of tax reform in a global economy, 193-206. Springer. 